\title{
SEJARAH MUNCULNYA ISU-ISU SOTEREOLOGI
}

\section{Charles Yermias Boimau}

Sekolah Tinggi Teologi Efata, Salatiga charlesmantull01@gmail.com

\begin{tabular}{|l||l||l|}
\hline Diterima : 17 Desember 2021 & Direvisi : 19 Desember 2021 & Disetujui : 20 Desember 2021 \\
\hline
\end{tabular}

\section{ABSTRACT}

Sotereological issues have always been an important talking point in the history of the development of Christian theology. The three important issues on which this article is based are 1) Are sinners saved only by God's grace alone? 2) Can man seek his own salvation? 3) Does man need to work with God in his salvation? By paying attention to these three issues, the purpose of the study is 1) to know the views that sinners are saved only by faith alone. 2) To understand the view that man can seek his own salvation? 3) To know the views that man needs to synergize with God in seeking his salvation? The research methodology used is literature research, with a descriptive approach. And the results show that Augustine, Marthin Luther and John Calvin were figures who emphasized salvation only by the Grace of God. Modern theologians emphasize human effort as a prinadi. Clement, Polycarp, Semi Pelagius, and Armenian emphasized the cooperation between God and man.

\section{ABSTRAK}

Isu-isu sotereologi senanantiasa menjadi pembicaraan yang penting dalam sejarah perkembangan teologi Kristen. Tiga isu penting yang menjadi dasar pembahasan dalam tulisan ini adalah 1) Apakah manusia berdosa diselamatkan hanya oleh hanya anugrah Allah saja? 2) Apakah manusia dapat mengusahakan keselamatannya sendiri? 3) Apakah manusia perlu bersinergi dengan Allah dalam mengusahakan keselamatannya? Dengan memperhatikan tiga isu tersebut maka tujuan penelitian adalah 1) untuk mengetahui pandangan-pandangan bahwa orang berdosa diselamatkan hanya oleh iman saja. 2) untuk mengerahui pandangan-pandangan bahwa manusia dapat mengusahakan keselamatannya sendiri? 3) untuk mengetahui pandanganpandangan bahwa manusia perlu bersinergi dengan Allah dalam mengusahakan keselamatannya?. Metodologi penelitian yang digunakan adalah penelitian kepustakaan, dengan pendekatan deskriptif. Dan hasil penelitian menunjukkan bahwa Agustinus, Marthin Luther dan John Calvin adalah tokoh-tokoh yang menekankan tentang keselamatan hanya oleh Anugrah Allah. Para teolog modern menekankan pada usaha manusia secar prinadi. Sedangkan Clement, Polikarpus, Semi Pelagius, dan Armenian menekankan pada kerjasaman antara Allah dan manusia.

Kata Kunci : Sejarah, Isu-Isu Sotereologi, Keselamatan 


\section{PENDAHULUAN}

Isu-Isu sotereologi seperti keselamatan manusia, pengampunan dosa, anugrah Allah, predestinasi dan pemilihan Allah, dan cara memperoleh keselamatan selalu menjadi pembicaraan yang menarik dalam sejarah perkembangan teologi Kristen. Isu-isu tersebut merefleksikan secara metodis dan sistematis tentang karya Allah bagi manusia yang telah jatuh dalam dosa. Menanggapi isu-isu tersebut, tidak semua teolog memiliki pandangan yang sama. Dalam setiap periode perkembangan sejarah teologi sejak abad pertama sampai sekarang, ${ }^{1}$ terdapat perbedaan pandangan di antara para teolog tentang keselamatan di dalam Tuhan Yesus Kristus. Sebagai contoh perdebatan predestinasi Calvin dan Armenian. Calvin berpendapat bahwa manusia percaya karena dipilih Allah. Sedangkan Armenian berpandangan bahwa manusia dipilih Allah karena ia percaya. ${ }^{2}$ Perdebatan ini telah diselesaikan dalam sinode di Dordrecht tahun 1610 1619 dengan kekalahan Armenianisme, ${ }^{3}$ namun pengaruh pengajaran Armenian masih terasa sampai sekarang ini.

Alkitab menyatakan bahwa satu-satunya pribadi yang memberikan keselamatan kepada manusia berdosa adalah Yesus Kristus. Yesus adalah penyelamat yang menyelamatkan umat-Nya dari dosa mereka (Matius 1:21). Pentingnya Yesus sebagai Penyelamat dijelaskan oleh Alister E. Mcgrath bahwa keselamatan terhubung dengan Yesus Kristus karena inkarnasi,, kematian dan

\footnotetext{
${ }^{1}$ Enns Paul, The Moody Handbook Of Theology, 2nd ed. (Malang: Literatur SAAT, 2010), 20. Enns membagi
} periode sejarah teologi dalam 4 periode yakni periode permulaan (1-590 AD), periode pertengahan (590 AD-1517), periode reformasi (1517-1750), dan teologi modern (1750-sekarang). Sedangkan Alister Mc Grath dalam bukunya: Christian Theology in Introduction, (Autralia: Blackwell Publishing), 2001, hal. 4, membagi periode sejarah teologi ke dalam 4 periode namun sedikit berbeda dengan Enns, yakni: the patristic period (periode bapak-bapak gereja) tahun 100-451, the Middle Ages and Renaissance (Abad Pertengahan dan Zaman Renaisanse) tahun (1050 - 1500), the Reformation and post Reformation Periods (Periode Reformasi dan Pasca Reformasi) tahun 1500-1750, dan the modern period (periode modern) tahun 1750 sampai sekarang.

\footnotetext{
2 Hadiwijono Harun, Teologi Reformasi Abad Ke 20, 6th ed. (Jakarta: BPK Gunung Mulia, 2004), 2.

3 Ibid.
} 


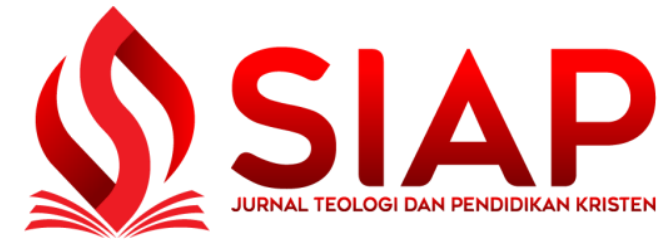

Vol. 10, No. 2 (Desember 2021)

Available Online at :

https://ejournal.sttjki.ac.id/index.php/siap/index

ISSN : 2302-5336X (Cetak) 2808-0459 (Online)

kebangkitan-Nya. Kemudian keselamatan dibentuk oleh Yesus Kristus karena kehidupan orang percaya yang berusaha terus menerus untuk meniru Kristus (imitate Christ) dan kehidupan Kristen adalah sebuah proses untuk menjadi serupa dengan Kristus (being conformed to Christ). ${ }^{4}$

Keselamatan di dalam Yesus ditujukan kepada seisi dunia yang percaya kepada-Nya (Yohanes 3:16). Mengapa seiisi dunia? Karena semua orang telah telah berdosa dan kehilangan kemuliaan Allah (Roma 3:23). Melalui kematian-Nya di atas kayu salib Yesus menyelamatkan seisi dunia. Setelah kebangkitan-Nya ia memerintahkan murid-murid-Nya untuk memberitakan Injil ke seluruh dunia, agar setiap orang yang percaya beroleh keselamatan (Mrk 16:14-15). Injil adalah berita yang utuh tentang karya Allah di dalam Tuhan Yesus untuk menyelamatkan orang berdosa. Dengan demikian, maka keselamatan sangat berhubungan dengan persoalan paling penting dengan eksistensi manusia ${ }^{5}$, yakni kejatuhan dalam dosa dan tindakan penyelamatan yang dilakukan Allah bagi manusia.

Dengan memperhatikan karya penyelamatan Allah bagi manusia berdosa, maka peneliti mempertanyakan tiga isu penting berkenaan dengan keselamatan, yakni 1) Apakah manusia berdosa diselamatkan hanya oleh hanya anugrah Allah saja? 2) Apakah manusia dapat mengusahakan keselamatannya sendiri? 3) Apakah manusia perlu bersinergi dengan Allah dalam mengusahakan keselamatannya? Ketiga pertanyaan ini adalah pertanyaan-pertanyaan yang menjadi isu perdebatan di antara para teolog dalam sejarah pergumulan teologi Kristen tentang Keselamatan.

Untuk menjawab ketiga pertanyaan di atas maka peneliti akan melakukan membahas tentang sejarah isu-isu sotereologi yang muncul dalam perjalanan teologi Kristen sejak abad pertama sampai sekarang, tentang: 1) pandangan bahwa orang berdosa diselamatkan hanya oleh iman saja. 2) pandangan bahwa manusia dapat mengusahakan keselamatannya sendiri? 3)

${ }^{4}$ McGrath Alister E., Christian Theology An Introduction, 2nd ed. (Australia: Blackwell Publishing, 2008), 407.

${ }^{5}$ Erickson Millard J, Teologi Kristen Volume 3, 2nd ed. (Malang: Gandum Mas, 2018), 70. 

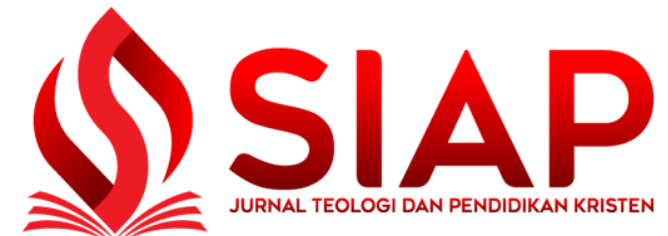

Vol. 10, No. 2 (Desember 2021)

Available Online at :

https://ejournal.sttjki.ac.id/index.php/siap/index

ISSN : 2302-5336X (Cetak) 2808-0459 (Online)

pandangan bahwa manusia perlu bersinergi dengan Allah dalam mengusahakan keselamatannya?

\section{METODOLOGI}

Metodologi penelitian yang digunakan adalah metode library research, dengan pendekatan deskriptif. Tempat penelitian dilakukan di perpustakaan STT Efata Salatiga. Sumber utama penelitian adalah Alkitab, dan sumber penunjang lainnya adalah buku-buku teologi, buku sejarah dan ensiklopedi.

\section{TEMUAN DAN PEMBAHASAN}

\section{Pengertian Sotereologi}

Soteriologi adalah istilah yang sangat umum dijumpai dalam dunia teologi. Istilah ini

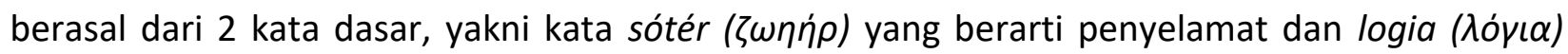
artinya perkataan, ajaran. Browing mengartikan sotereologi sebagai ajaran tentang keselamatan menurut agama Kristen ${ }^{6}$.

\section{Konsep Sotereologi dalam Perjanjian Lama}

Secara harfiah, kata keselamatan dalam bahasa Ibrani yesyu'a berarti tindak, hasil dari pembebasan, pemeliharaan dari bahaya dan penyakit, yang mencakup keselamatan, kesehatan dan kemakmuran. ${ }^{7}$ Konsep keselamatan dalam Perjanjian Lama, ditujukan kepada manusia dan kepada Allah. Manusia terancam karena sakit penyakit, bencana alam, penganiyaan oleh musuh dan bahkan kematian. Dalam persekutuan umat Allah dengan Tuhan, kenyataan hidup yang terancam memerlukan kelepasan dari Allah. Dan kelepasan itu bersifat kesukaan duniawi. Tuhan memberikan keselamatan secara langsung ataupun tidak langsung melalui bapak leluhur, hakim, imam, raja dan nabi.

\footnotetext{
${ }^{6}$ Browning W.R.F, Kamus Alkitab (Jakarta: BPK Gunung Mulia, 2008).

${ }^{7}$ Douglas J.D., Ensiklopedi Alkitab Masa Kini Jilid II, 2nd ed. (Jakarta: Yayasan Komunikasi Bina Kasih, 1996),
} 375. 


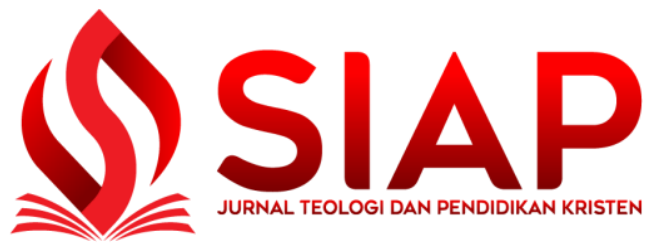

Vol. 10, No. 2 (Desember 2021)

Available Online at :

https://ejournal.sttjki.ac.id/index.php/siap/index

ISSN : 2302-5336X (Cetak) 2808-0459 (Online)

Hukum Taurat ditegakkan namun tidak sanggup memberi keselamatan penuh, walaupun hukum bertujuan baik untuk mencapai tuntutan Allah dan kesejahteraan manusia. Untuk mencegah manusia berdosa di hadapan Allah, maka pada hukum yang ada dibuatlah aturan moral. Namun fokusnya pada peraturan lahiriah, bukan pada spiritual. Dan pencapaian manusia untuk memperoleh keselamatan lebih kepada sikap membenarkan diri sendiri. ${ }^{8}$ Memperhatikan kehidupan spiritual umat Israel seperti ini, para nabi menekankan pentingnya perubahan batin, dan menubuatkan datangnya keselamatan mesianis apokaliptik sesuai dengan janji Allah (Yes 44:17; Dan 7:13). Ajaran Perjanjian Lama tentang keselamatan mencapai puncaknya dalam gambaran Hamba Yang Menderita (Yes 53), yang digenapi oleh Yesus Kristus dalam Perjanjian Baru. $^{9}$

Dengan demikian konsep sotereologi dalam Perjanjian Lama lebih menekankan pada keselamatan lahirian bukan pada spiritual.

\section{Konsep Sotereologi Dalam Perjanjian Baru}

Kata "selamat" dalam Injil Sinoptik dikaitkan dengan pelayanan dan kedatangan Yesus (Mrk 3:4; Luk 4:18; 9:56; Mat 18:11; 20:28) dan yang dituntut dari manusia adalah penyesalan akan dosa, perubahan sifat, pasrah kepada Allah dan penyangkalan segala sesuatu demi Kristus (Mrk 8:35; Luk 7:50; 8:12; 13:24; Mat 10:22). Kata selamat dalam Injil Sinoptik menyatakan bahwa keselamatan telah nyata dalam pelayanan Yesus terutama dalam kematianNya. Keselamatan dalam Kisah Para Rasul, dimulai dengan penyerahan diri kepada Tuhan Yesus (Kpr 2:40); pertobatan (Kpr 11:18); pengampunan dosa dan penerimaan Roh Kudus.

Dalam surat-surat Paulus, keselamatan disediakan sebagai anugrah Allah yang adil, kepada orang berdosa yang tidak layak diselamatkan. Orang berdosa oleh iman percaya kepada keadilan Kristus yang sudah menebus dia dengan kematian-Nya dan membangkitkan dia oleh kebangkitan-Nya. Allah demi Kristus membenarkan pendosa yang tidak layak itu, membenarkan dosa-dosanya, mendamaikan diri-Nya sendiri di dalam dan melalui Kristus yang sudah membuat

\footnotetext{
8 Ibid.

${ }^{9}$ Ibid.
} 


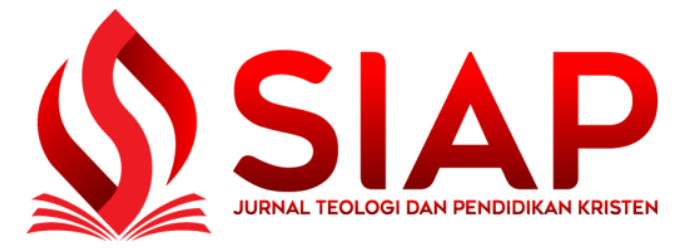

Vol. 10, No. 2 (Desember 2021)

Available Online at :

https://ejournal.sttjki.ac.id/index.php/siap/index

ISSN : 2302-5336X (Cetak) 2808-0459 (Online)

perdamaian melalui darah salibNya (2 Kor 5:18; Rm 5:11; Kol 1:20), mengangkatnya menjadi keluarganNya (Gal 4:5; Ef 1:13; 2 Kor 1:22), memberinya materai dan Roh Kudus dalam hatinya dengan demikian menjadikannya makluk baru.

Dalam Ibrani, keselamatan adalah anugrah Kristus bagi orang yang menantikan Dia (Ibr 9:28). Dalam Kitab Yakobus, keselamatan bukan oleh iman saja, melainkan oleh perbuatan (Yak 2:24). Yakobus bukan melupakan iman, tetapi iman nampak dalam perbuatan yang menunjukkan kekuatan penyelamatan yang bekerja melalui firman Allah di dalam hati. Dengan demikian dari Perjanjian Baru, kita dapat menyimpulkan bahwa keselamatan anugrah Allah yang diterima dengan iman iman kepada Tuhan Yesus Kristus dan keselamatan menjadi sempurna oleh karena perbuatan.

\section{Sejarah Isu-Isu munculnya Sotereologi}

Pembahasan sejarah munculnya isu-isu sotereologi didasarkan pada perkembangan teologi Kristen, sejak abad pertama sampai pada masa kini. Perkembangan ini oleh Paul Enns dibagi dalam dalam empat periode perkembangan teologi yakni: Periode abad permulaan (tahun 1 - 590 M), periode abad pertengahan (tahun 590 M - 1517). periode masa Reformasi (tahun $500-1500 \mathrm{M}$ ), dan periode abad modern (tahun 1800 -sekarang sekarang) ${ }^{10}$

Isu-Isu Sotereologi Pada abad Permulaan

Isu-isu sotereologi pada abad permulaan adalah: pertama, Pribadi Yesus Kristus sebagai Penyelamat. Pada abad kedua ajaran gnostic menyerang gereja berkenaan dengan pribadi Yesus sebagai Logos yang menjadi pengantara antara Allah dan Manusia. Bapak gereja Ireneus (130200 M) melawan ajaran gnostic dengan mengajarkan bahwa:

Adam dan semua manusia diciptakan untuk hidup kekal, namun karena jatuh ke dalam dosa, maka manusia mengalami kebinasaan. Untuk melepaskan manusia, Allah mengutus Anaknya, yaitu Logos yang berinkarnasi menjadi manusia. Kristus menjembatani manusia berdosa dengan Allah yang kekal. Kristus adalah Adam kedua yang menggenapi seluruh tuntutan Allah, yang disia-siakan Adam pertama. Melalui kebangkitannya Kristus

\footnotetext{
${ }^{10}$ Enns Paul, The Moody Handbook Of Theology, 29.
} 


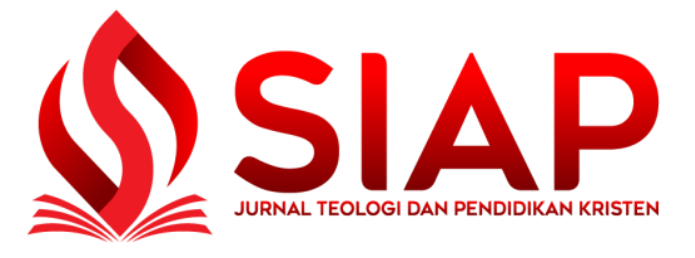

Vol. 10, No. 2 (Desember 2021)

Available Online at :

https://ejournal.sttjki.ac.id/index.php/siap/index

ISSN : 2302-5336X (Cetak) 2808-0459 (Online)

memberikan jaminan kekal kepada mereka yang percaya kepada-Nya. Roh Kudus pada masa sekarang memberikan hidup kekal kepada semua orang percaya melalui Baptisan dan perjamuan. Kristus memperstukan segala yang di sorga dan di bumi (Ef 1:10). Allah dan manusia yang dulu terpisah oleh dosa, sekarang dihubungkan dan disatukan oleh Kristus. Allah menjadi manusia agar manusia mendapatkan hidup kekal. ${ }^{11}$

Melalui pengajarannya Irenues menekankan keutamaan Kristus sebagai Penyelamat. Namun ia kurang menekankan pembenaran oleh iman dan salib Kristus. Hal ini terjadi karena isu yang muncul pada saat itu bukanlah pertentangan antara dosa dan anugrah Allah, melainkan pertentangan antara akibat dosa yaitu kebinasaan dan akibat anugrah Allah yang hidup kekal.

Kedua, keselamatan diperoleh melalui darah Kristus dan pertobatan. Clemens dari Aleksandria (pertengahan abad ke-2) mengajarkan bahwa keselamatan hanyalah melalui darah Kristus. Darah itu telah ditumpahkan untuk memberikan anugrah pengampunan yang mendatangkan keselamatan bagi manusia di seluruh dunia ${ }^{12}$. Igantius (35-107 M) menekankan tentnag iman melalui darah Kristus yang memberikan keselamatan. ${ }^{13}$ Dan Polikarpus menyatakan bahwa Kristus "memikul dosa kita pada tubuh-Nya di atas kayu salib"14. Untuk menghasilkan keselamatan bapak-bapak Apostolik mengutamakan perbuatan sebagai usaha dari keselamatan. Clement mengutamakan ketaatan untuk mencapai keselamatan berdasarkan teladan iman tokoh-tokoh Perjanjian Lama seperti Henokh, Nuh, Abraham, Lot dan Rahab. ${ }^{15}$ Keselamatan ditunjukkan dalam kehidupan iman dengan hidup dalam kekudusan dan kebenaran, baptisan, menjaga hukum-hukum Tuhan, hidup dalam kasih, meninggalkan hawa nafsu dunia, dan melakukan kebenaran ${ }^{16}$

\footnotetext{
${ }^{11}$ Berkhof H.; Enklaar I.H., Sejarah Gereja, 12th ed. (Jakarta: BPK Gunung Mulia, 1994), 40.

12 Enns Paul, The Moody Handbook Of Theology, 27.

${ }^{13}$ Ibid.

${ }^{14}$ Ibid., 46.

${ }^{15}$ Ibid.

${ }^{16} \mathrm{Ibid}$.
} 


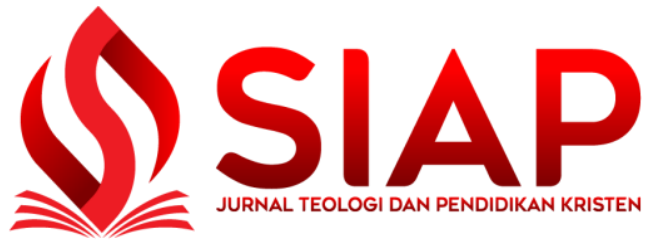

Vol. 10, No. 2 (Desember 2021)

Available Online at :

https://ejournal.sttjki.ac.id/index.php/siap/index

ISSN : 2302-5336X (Cetak) 2808-0459(Online)

Ketiga, keselamatan oleh Anugrah Allah. Isu ini dimunculkan oleh Agustinus (350-430 M). Pandangan Sotereologinya dirumuskan secara bertahap. Pada awal pertobatannya, ia menyatakan bahwa keselamatan terjadi karena kasih karunia Allah dan pertolongan Roh Kudus. Tahun 397 M setelah ia melakukan penelitian mendalam tentang tulisan-tulisan Paulus, ia mendapatkan pemahaman yang kuat bahwa tentang keselamatan adalah anugrah Allah. Pandangannya ini semakin kuat dikembangkannya ketika ia melawan Pelagius, dengan menyatakan bahwa oleh rahmat-Nya, Allah telah memilih sejumlah orang, bukan semua orang untuk diselamatkan. ${ }^{17}$

Pandangan keselamatan Agustinus berasal dari ajaran Rasul Paulus bahwa keselamatan bukanlah usaha manusia, tetapi berdasarkan anugrah Allah. ${ }^{18}$ Dalam mengembangkan pemikiran teologisnya Agustinus bertitik tolak dari kehendak Allah bagi Adam sebelum jatuh kedalam dosa. la berpandangan bahwa Tuhan memberikan kehendak bebas bagi Adam. Tuhan menghendakinya untuk melakukan hal yang baik. Tuhan juga memberikan pertolongan anugrah baginya sehingga ia tidak dapat berbuat dosa. Namun kehendaknya sendirilah yang menyebabkannya jatuh dalam dosa. Akibatnya ia kehilangan persekutuan dengan Tuhan. Anugrah pertolongan Tuhan juga hilang, dan sejak saat itu ia tidak dapat tidak berdosa. Dosa masuk melalui Adam dan semua keturunannya ikut berdosa (Roma 5:12). Dalam keberdosaan manusia, Tuhan memilih orangorang tertentu untuk mendapatkan rahmatNya supaya mereka diselamatkan. Pilihan Tuhan ini disebut predestinasi. ${ }^{19}$ Jadi teologi Agustinus berpusat pada anugrah Tuhan yang bebas untuk mencari dan menyelamatkan manusia.

Pada masa yang sama Agustinus melawan Pelagius. Pelagius berpandangan bahwa dosa Adam tidak menghilangkan kehendak bebas manusia. Manusia dilahirkan dalam keadaan tidak berdosa. Jadi tidak ada dosa turunan. Bayi tidak perlu dibabtis karena tidak ada dosa asal. Dosa

\footnotetext{
17 Tony Lane, Runtut Pijar Sejarah Pemikiran Kristen, 6th ed. (Jakarta: BPK Gunung Mulia, 2005$), 42$.

${ }^{18}$ Berkhof H.; Enklaar I.H., Sejarah Gereja, 67.

19 lbid., 68.
} 
tidak terletak pada sifat manusia tetapi pada pada kehendaknya. Saat manusia berkehendak jahat disitulah ia berbuat dosa. Manusia berdosa karena terpengaruh lingkungannya, karena itua ada manusia yang tidak berdosa seumur hidupnya. Kematian bukan hukuman dosa, tetapi hukum alam. Keselamatan diperoleh manusia berdasarkan kebaikan yang dilakukan sesuai kehendak bebasnya. ${ }^{20}$ Keselamatan tidak perlu Taurat dan Injil ataupun rahmat Allah. Hal ini disebabkan oleh sifat dasar manusia yang baik dan tidak berdosa. ${ }^{21}$

Untuk mengatasi meluasnya pandangan Pelagius, maka Tahun 418, di Carthage, diadakan sidang untuk mengambil keputusan bahwa: a) Adam mati karena dosanya; b) Anak kecil juga perlu dibabtis baru dosa asalnya dapat diampuni; c) hanya barsandar pada anugrah baru dapat hidup secara layak; d) dalam dunia ini tidak ada kemungkinan untuk tidak berdosa. Pandangan Pelagius kemudian dilawan oleh Agutinus bahwa manusia diselamatkan berdasarkan anugrah Allah. Keselamatan itu diberikan cuma-cuma kepada manusia.

Pandangan sotereologi Agustinus menimbulkan perdebatan dari gereja. Jikalau keselamatan hanya berdasarkan pemilihan dan anugrah, dimanakah penawaran keselamatan kepada semua manusia dan dimanakah tanggung jawab manusia? Pemikiran ini menimbulkan perdebatan di dalam gereja barat selama satu abad. Lalu muncullah pengajaran semi pelagian, yang mencari jalan tengah agar moralitas Kristen dipertahankan. Menurut mereka: kehendak manusia hanya dilemahkan pada waktu kejatuhan Adam, sehingga manusia dapat berbuat baik lagi. la tidak mati (Agustinus) dan tidak sehat (Pelagius), tetapi sakit. Untuk mendapatkan keselamatan manusia dan Allah bekerja bersama-sama (sinergisme) ${ }^{22}$. Pandangan ini menolak predestinasi. Bagi mereka keselamatan dan kebinasaan ditentukan oleh sikap masing-masing pribadi. $^{23}$

\section{0 lbid., 69.}

${ }^{21}$ Matalu Muriwali Yanto, Dogmatika Kristen Dari Perspektif Reformed, 3rd ed. (Malang: GKKR (Gereja Kebangunan Kristen Reformed), 2017), 673.

\footnotetext{
22 Ibid.

${ }^{23}$ Berkhof H.; Enklaar I.H., Sejarah Gereja, 69.
} 


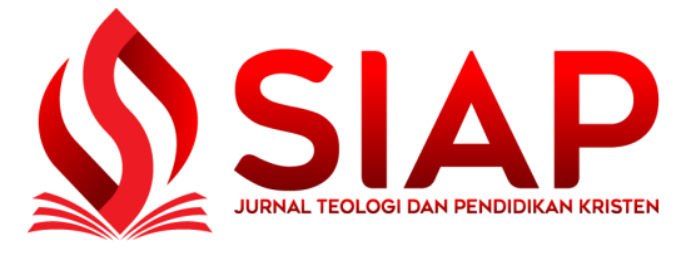

Vol. 10, No. 2 (Desember 2021)

Available Online at :

https://ejournal.sttjki.ac.id/index.php/siap/index

ISSN : 2302-5336X (Cetak) 2808-0459 (Online)

Isu Soteriologi Abad Pertengahan

Pada abad ke delapan, gereja Roma mengakui tujuh sakramen, yakni Perjamuan Kudus , baptisan air , konfirmasi, pengakuan dosa, urapan penghabisan, perkawinan dan penahbisan imam. Gereja Roma mengajarkan bahwa anugrah dan keselamatan hanya dapat diterima manusia dengan menerima sakramen. Sakramen-sakramen dipandang sebagai saluran-saluran yang melaluinya dicurahkan rahmat dari atas untuk memasuki, memenuhi, menyucikan dan menyelamatkan manusia lahir batin. Imamlah yang berkuasa membuka atau menutup aliran anugrah (kasih karunia) itu. ${ }^{24}$ Dengan menerapkan pemahaman ini, maka keselamatan tidak dipandangan sebagai hubungan pribadi dengan Allah, tetapi hubungan yang tepat dengan gereja. ${ }^{25}$ Pengajaran ini menyimpang dari kebenaran Alkitabiah. Isu-isu lain yang muncul pada abad pertengahan mengenai sotereologi adalah pembahasan tentang pebusan, anugrah Allah, iman dan perbuatan baik, serta justifikasi.

\section{Penebusan.}

Anselmus (1033-1109) menyatakan bahwa kemuliaan yang seharusnya ditujukan kepada Allah, telah dirampas dosa manusia. Untuk mempertahankan kemuliaan-Nya Allah bisa menggunakan dua opsi, yakni memilih untuk menghukum manusia, atau menyediakan pemuasan melalui Putra-Nya sebagai pemberian. Allah memilih opsi kedua. Karena itu Yesus Kristus menerima upah, yang diteruskan kepada manusia berdosa dalam bentuk pengampunan. Peter Abelard (1079-1142) berbeda pandangan dengan Anselmus. la menganut pandangan pengaruh moral. Peter mengajarkan bahwa Allah tidak menuntut kematian Kristus supaya menebus dosa. Sebaliknya, dengan kematian Kristus, kasih Allah telah dinyatakan bagi manusia. Menurutnya, Allah dengan bebas mengampuni orang-orang berdosa karena kasih-Nya yang terbukti dalam kematian Kristus. ${ }^{26}$

\footnotetext{
${ }^{24}$ Ibid., 111.

${ }^{25}$ Lutzer Erwin W, Teologi Kontemporer, 3rd ed. (Malang: Gandum Mas, 2005), 10.

${ }^{26}$ Enns Paul, The Moody Handbook Of Theology, 61.
} 


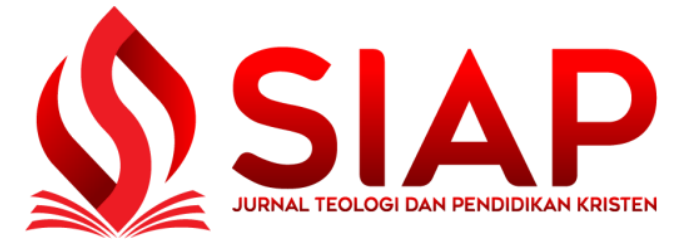

Vol. 10, No. 2 (Desember 2021)

Available Online at :

https://ejournal.sttjki.ac.id/index.php/siap/index

ISSN : 2302-5336X (Cetak) 2808-0459 (Online)

Pemikiran Abelard ditolak oleh Bernard dari Clairvaux (1090-1153). la berpandangan bahwa penebusan pada orang percaya terjadi melalu darah Kristus, bukan teladan-Nya. Peter Lombard (1096-1160) menggabungkan konsep Anselmus dan Abelard. Ia menyimpulkan Kristus mati bagi orang-orang berdosa, Kematian-Nya ini telah mendorong mereka untuk mencintai Allah. Hasilnya mereka dibebaskan dari dosa. Aquinas (1225-1274) juga merenungkan pandangan dari Abelard dan Anselmu. Baginya Yesus menyatakan kesempurnaan bagi manusia, karena la adalah Kepala bagi mereka. Kristus adalah guru dan teladan bagi manusia berdasarkan pengajaran-Nya, tindakan-Nya, dan penderitaanNya. Semua yang dilakukan Yesus untuk menyatakan kasih Allah dan menghidupkan dalam hati manusia kasih yang responsive kepada Allah. 27

Anugrah Allah

Pada Abad Pertengahan, pengajaran sotereologi bergerak ke arah Semi Pelagianisme. Secara umun gereja mengajarkan bahwa sewaktu kejatuhan manusia di taman Eden, kehendak manusia tidak musnah. Oleh sebab itu manusia dapat bersinergi dengan Allah untuk mencapai keselamatan. Berbeda dengan gereja, teolog skolastik menekankan pada kebutuhan anugrah Allah dalam keselamatan dengan berbagai definisi. Thomas Aquinas mengajarkan bahwa kebutuhan mendasar dalam keselamatan adalah anugrah Allah. Menurutnya manusia tidak mungkin berbalik dari keadaan berdosanya kepada kebenaran apabila ia terpisah dari Allah. Menurutnya anugrah terdiri dari dua bagian, yakni anugrah bebas dan anugrah pengudusan. Pengetahuan, perbuatan mukjizat dan komunikasi adalah anugrah umum. Sedangkan anugrah operatif manusia bersinergi dengan Allah ${ }^{28}$.

Iman

Aspek iman dalam pandangan teolog Abad adalah "fides informis", yakni pengetahaun tentang pokok-pokok ajaran gereja, dan "fides informata", yakni keyakinan yang ditunjukkan

\footnotetext{
27 Ibid.

28 Ibid., 62.
} 


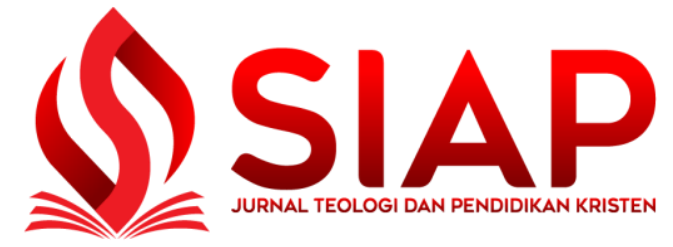

dalam praktek kasih. Dari kedua aspek ini, hanya keselamatan dan justifikasi yang dihasilkan dari fides informata. Namun, pusat dari kehidupan rohani bukanlah pada iman, melainkan pada kasih dan perbuatan baik. ${ }^{29}$

Justifikasi

Justifikasi pada era Skolastik, tidak dihubungkan dengan tindakan hukum Allah, tetapi sebagai bentuk kerjasama yang melaluinya Allah memberikan anugrah pengudusan kepada setiap pribadi. Kelemahan pengajaran ini adalah putusan Allah tidak memberikan kepastian keselamatan, sebab tidak mudah mencapainya ${ }^{30}$

\section{Isu-isu Sotereologi pada Jaman Reformasi}

Isu sotereologi pada jaman Reformasi (1517-1750), tidak jauh berbeda dengan pandangan-padangan sebelumnya, namun mendapatkan penekanan yang lebih mendalam. 3 pokok utama yang menjadi isu sotereologi pada masa ini adalah: predestinasi, penebusan, iman dan perbuatan.

Predestinasi

John Calvin mengajarkan bahwa keselamatan mutlak didasarkan pada anugrah Tuhan, ${ }^{31}$ yang didasarkan pada ketetapan kekal Allah. Oleh kedaulatan-Nya, setiap peristiwa apapun yang terjadi pada tiap individu, dipahami sebagai ketetapan Allah bagi pribadi tersebut. Teologia kedaulatan Allah yang diajarkan Calvin pada dasarnya berasal dari Augustiniannisme. ${ }^{32}$ Bagi Calvin Predestinasi adalah ketetapan kekal dari Allah yang telah menetapkan nasip setiap orang di dalam dirinya. Pokok ajaran predestinasi Calvin meliputi pemilihan orang-orang yang akan diselamatkan dan reprobasi, yakni penolakan Allah terhadap orang berdosa lainnya, akibatnya mereka mendapatkan hukuman kekal. Calvin menegaskan kedua pandangan ini dalam

\footnotetext{
29 Ibid.

30 Ibid.
}

31 Matalu Muriwali Yanto, Dogmatika Kristen Dari Perspektif Reformed, 673.

${ }^{32}$ Gary Scott Hoffecker, W Andrew; Smith, Membangun Wawasan Dunia Kristen Volume 2: Alam Semesta, Masyarakat Dan Etika, ed. Hoffecker W. Andrew, 1st ed. (Surabaya: Momentum, 2018), 139. 


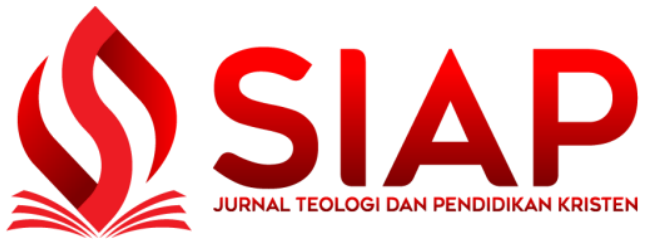

Vol. 10, No. 2 (Desember 2021)

Available Online at :

https://ejournal.sttjki.ac.id/index.php/siap/index

ISSN : 2302-5336X (Cetak) 2808-0459 (Online)

pengajarannya. Dipilih untuk mendapatkan keselamatan adalah anugrah Allah, sebaliknya ditolak untuk mendapatkan keselamatan disebabkan oleh dosa dan kesalahan. Pokok ajaran predestinasi diajarkan oleh Marthin Luther sebagai keharusan karena kerusakan total dan ketidakmampuan manusia untuk menyelamatkan dirinya. ${ }^{33}$

Penebusan

Para Reformator lebih mengikuti pandangan Anselmus tentang penebusan, bahwa Kristus Yesus mati untuk memuaskan keadilan Allah. Anselmus berpandangan bahwa kemuliaan Allah telah dirampas oleh dosa manusia. Oleh sebab kematian Yesus bertujuan mengembalikan kemuliaan Allah yang telah dirampas dosa. Luther menyatakan bahwa "kematian Kristus menjadikannya milik Allah, dan membawanya hidup di dalam kerajaan-Nya. ${ }^{34}$ Calvin menyatakan bahwa kematian Kristus merupakan penebusan yang ditujukan hanya bagi orang-orang khusus yang mendapatkan pilihan Allah. ${ }^{35}$

Socinus membantah pandangan Anselmus tentang keadilan Allah yang mengharuskan kematian Yesus. Menurutnya tanpa penebusan Kristus, orang-orang berdosa dapat diampuni Allah berdasarkan kehendak-Nya. Kemurahan adalah dasar pengampunan Allah, bukan kematian Kristus. Tuhan Allah hanya meminta orang-orang berdosa bertobat yang selanjutnya menunjukkan kerinduannya pada hukum Allah. Kematian Kristus bagi Socinus hanyalah memberikan inspirasi tentang teladan ketaatan kepada Allah. Pemikiran Socinus serasi dengan Pelagianisme, dan Unitarianisme pada waktu sekarang. ${ }^{36}$

Padangan tokoh reformasi lainnya tentang penebusan berasal dari Hugo Grotius yang lahir pada akhir abad ke-16. la mengajarkan tentang Allah tidak menuntut pembayaran komplit untuk pelanggaran dosa. Kematian Kristus adalah tanda pembayaran Allah. Dengan menerima pembayaran melalui kematian Kristus, Allah mengesampingkan tuntutan dari hukum. Perjanjian

\footnotetext{
${ }^{33}$ Enns Paul, The Moody Handbook Of Theology, 71.

34 Ibid., 77.

${ }^{35}$ Erickson Millard J, Teologi Kristen Volume 3, 77.

36 Ibid., 78.
} 


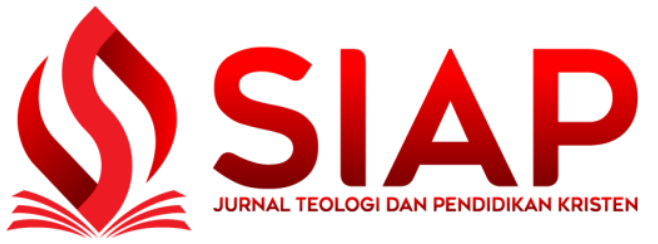

Vol. 10, No. 2 (Desember 2021)

Available Online at :

https://ejournal.sttjki.ac.id/index.php/siap/index

ISSN : 2302-5336X (Cetak) 2808-0459 (Online)

Baru mengajarkan kematian Kristus telah memuaskan tuntutan hukum itu. ${ }^{37}$ Teologi Arminian menganalogikan pengorbanan Kristus dengan persembahan korban yang dilakukan dalam Perjanjian Lama. Pengorbanan Lembu, atau domba dalam Perjanjian Lama bertujuan menyelamatkan orang-orang berdosa dari hukuman Allah. Pengorbanan Kristus bukan sebagai pembayaran hutang kepada Allah. Juga bukan sebagai bentuk pemuasan keadilan dari dosa. . ${ }^{38}$ Iman Dan Perbuatan

Luther menekankan keselamatan berdasarkan anugrah melalui iman. la mengajarkan tentang landasan keselamatan dan keadilan Allah bagi manusia berdosa hanya berdasarkan anugrah Allah. Allah yang mengampuni dosa-dosa dan menyatakan kebenaran dari Kristus pada mereka yang percaya. Luther juga mengajarkan bahwa perbuatan baik tidak mendapatkan bagian dalam keselamatan. Perbuatan baik adalah hasil dari keselamatan, dan tidak mengambil bagian dari keselamatan. Perbuatan baik ditemukan dalam hukum Taurat.

Calvin sependapat dengan Luther dalam pembenaran iman. Bagi Calvin, pembenaran adalah tindakan yang sah oleh Tuhan untuk menyatakan orang percaya benar, tindakan yang dilakukan oleh kasih karunia Tuhan. Dalam hubungan dengan Yakobus 2:20, Calvin mengajarkan bahwa pembenaran tidak ada hubungannya dengan pengenaan pembenaran, tetapi, seperti yang juga diajarkan Luther, karya bersaksi tentang realitas pembenaran. Dengan demikian Calvin mengajarkan pembenaran ganda. ${ }^{39}$

Tidak seperti ajaran Calvin tentang pilihan tanpa syarat, pengikut Armenia mengajarkan pilihan bersyarat, yakni Tuhan mengetahui orang-orang yang dipilih dan diselamatkan karena iman mereka kepada Yesus. Tetapi Kristus mati tidak hanya untuk orang-orang pilihan, tetapi untuk semua orang, sehingga mereka beroleh kebebasan percaya atau menolak Kristus. Bagi mereka yang percaya, mereka dapat menolak Roh Kudus dan kehilangan keselamatan.

\footnotetext{
${ }^{37} \mathrm{Ibid}$.

${ }^{38}$ Enns Paul, The Moody Handbook Of Theology, 80.

${ }^{39} \mathrm{Ibid}$.
} 


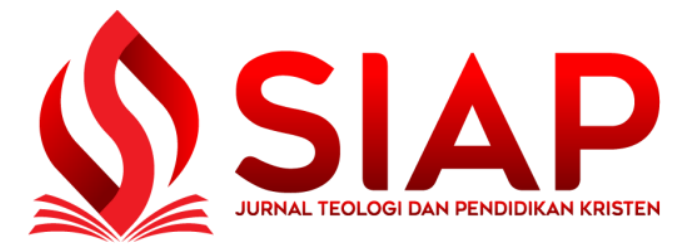

Vol. 10, No. 2 (Desember 2021)

Available Online at :

https://ejournal.sttjki.ac.id/index.php/siap/index

ISSN : 2302-5336X (Cetak) 2808-0459 (Online)

Isu Sotereologi Era Modern

Sotereologi era modern (1750-sekarang) lebih condong kepada filsafat bukan kepada Alkitab. Keselamatan menurut bapak teologi modern Freidrich Schleiermacher adalah anugrah, tetapi anugrah yang dimaksudkan adalah anugrah dalam bentuk "impulse" yang memungkinkan manusia memanfaatkan "anugrah umum" yang ada pada dirinya yaitu "God-consciousness" (kesadaran Tuhan). Dengan anugrah ini manusia bisa melatih kepekaan kesadaran Tuhannya. ${ }^{40}$ Yesus Kristus disebut "the Archetypal of God-consciousness" yaitu manusia yang secara khusus disediakan Allah untuk menjadi model bagaimana manusia seharusnya menghidupi kesadaran Tuhannya secara tepat. Keselamatan yang sejati bukan terjadi oleh karena iman kepada kematian Kristus. Keselamatan yang sejati adalah pengalaman hidup dengan kesadaran Tuhannya seperti Kristus yang memungkin akan menuju kepada puncak manifestasi kesadaran Tuhannya yaitu kerelaan mati seperti Kristus. Keselamatan dimulai dengan Allah yang memberikan "knowledge of Himself" (pengetahuan tentang Diri-Nya) pada manusia. ${ }^{41}$ Pandangan ini lebih menekankan pada usaha manusia untuk menyelamatkan dirinya.

Beberapa pandangan lain tentang isu sotereologi di Era Modern ini seperti yang terlihat pada beberapa pendangan teologi dibawah ini diantaranya:

\section{Teologi Pembebasan}

Pemahanan dari Teologi Pembebasan, bahwa keselamatan adalah pelepasan atau pembebasan dari penindasan dan eksploitasi kelompok penguasa kepada kelompok yang tidak berkuasa. ${ }^{42}$ Kitab Keluaran menjadi landasan pemikiran teologi pembebasan sebagaimana bangsa Israel adalah bangsa yang tertindas dan tidak berdaya. Demikian juga golongan masyarakat yang

${ }^{40}$ Susabda Yakub B., Seri Pengantar Teologi Modern 1, 2nd ed. (Jakarta: Lembaga Reformed Injili Lindonesia, 1993), 22.

41 Ibid.

${ }^{42}$ Erickson Millard J, Teologi Kristen Volume 3, 76. 


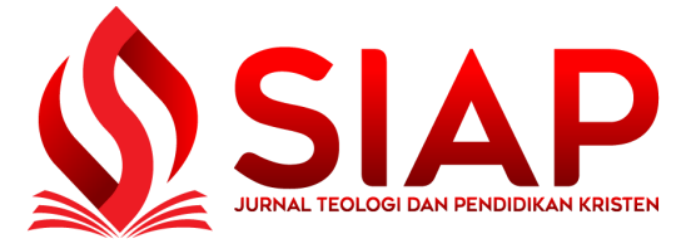

Vol. 10, No. 2 (Desember 2021)

Available Online at :

https://ejournal.sttjki.ac.id/index.php/siap/index

ISSN : 2302-5336X (Cetak) 2808-0459 (Online)

ditindas oleh kelompok penguasa perlu mendapatkan pembebasan seperti bangsa Israel. Beberapa faktor penyebab kebangkitan teologi pembebasan:

a) Teologi pembebasan menggunakan pemikiran Imanuel Kant, George W.F. Hegel dan Karl Marx.

b) Teologi pembebasan pemikiran Jurgen Moltman bahwa revolusi adalah cara untuk mencapai masa depan

c) Teologi pembebasan merupakan gerakan Roma Katolik di Amerika Latin, karena penindasan yang dilakukan oleh para diktator

Evaluasi terhadap teologi ini:

a) Teolog pembebasan menafsirkan Alkitab dengan cara yang berbeda dengan yang seharusnya. Misalnya kebangkitan Kristus ditafsirkan sebagai kelepasan dari kekuasanan penindas. Arti sebenarnya yakni pembebasan dosa diabaikan.

b) Menekankan pada keselamatan politis bukan keselamatan rohani.

c) Pengaharapan dari para teolog pembebasan tidak dilandaskan pada konsep Alkitabiah, tetapi pada konsep pengharapan Jurgen Moltman tentang menyadari masa depan, pada masa sekarang melalui cara-cara revolusionari

d) Teologi ini bertentangan dengan Alkitab ${ }^{43}$

Teologi Eksistensial

Pemahaman keselamatan dari teologi Eksistensial lebih dipengaruhi oleh filsafat Bultmann. Konsep Bultmann didasarkan oleh prinsip filosofis Martin Heidegger, bukan berdasarkan Alkitab. Prinsip tersebut adalah: ${ }^{44}$ 1) Perbedaan pengetahuan obyektif dan subyektif. Bultman menerapkan pengetahuan ini pada Alkitab. Ia menyatakan bahwa Alkitab bukan sumber obyektif tentang Allah, manusia dan keadaannya. Alkitab tidak memberikan laporan obyektif tentang peristiwa-peristiwa sesuai realitas. Alkitab hanya memberitakan dampak dari peristiwa tertentu. 2) Perbedaan keberadaan otentik dan tidak ontentik. Keberadaan

\footnotetext{
${ }^{43}$ Enns Paul, The Moody Handbook Of Theology, 257-258.

${ }^{44}$ Erickson Millard J, Teologi Kristen Volume 3, 81.
} 


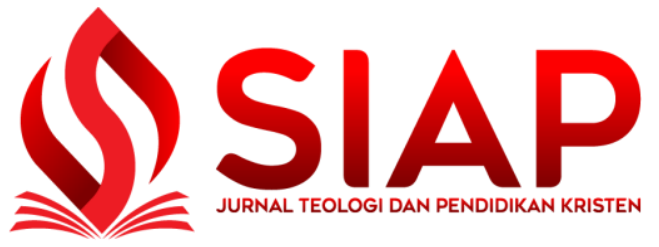

otentik berarti menjadi sebagaimana seharusnya, hidup sedemikian sehingga potensi yang ada dalam diri manusia bisa terwujud. Seseorang disebut tidak otentik ketika tidak menggunakan kemampuannya untuk menentukan pilihan dan bertindak dengna bebas. Bultman menerapkan konsep ini dengan menyatakan bahwa Manusia modern yang percaya dengan dirinya sendiri dapat memperoleh keselamatan melalui usahanya. Hal ini terjadi karena manusia otonom. Allah dan Injil memanggil manusia untuk menjadi dirinya sendiri, yaitu takdirnya yang asli. ${ }^{45}$

Dengan berlandaskan konsep tersebut, Bultman sampai pada kesimpulan bahwa keselamatan bukan suatu perubahan jiwa seperti yang dipahami sebagai pembaharuan, dan bukan pula suatu penyataan hukum bahwa kita dibenarkan dalam pandangan Allah, tetapi lebih merupakan suatu perubahan mendasar terhadap existens kita, yaitu seluruh pandangan kita dan perilaku kita. ${ }^{46}$ Bultaman tidak percaya adanya surga dan neraka karena keselamatan bagi Bultmann adalah 1) tidak ada sangkut paut dengan kelahiran baru yang melahirkan iman kepada “apa yang Allah telah lakukan dalam rencana keselamatan-Nya dalam sejarah". 2) tidak ada sangkut paut dengan anugrah keselamatan jiwa, pembaharuan hidup dan kehidupan kekal seperti yang tertulis di dalam Alkitab. ${ }^{47}$ Dengan demikian konsep keselamatan Bultmann tidak sesuai dengan padangan keselamatan yang diajarkan dalam Alkitab karena lebih menekankan pada usaha dan kekuatan manusia.

\section{Teologi Sekuler}

Pemahaman keselamatan dalam teologi secular adalah menolak pandangan tradisional bahwa keselamatan adalah anugrah Allah yang akan diterima dalam kekekalan. Keselamatan adalah saat di mana manusia menggunakan kemampuannya, tidak lagi bergantung pada Allah, berusaha mencapai tingkat kedewasaan, menegaskan dirinya sendiri, serta melibatkan diri di

\footnotetext{
45 Ibid., 84.

46 Ibid., 86.

${ }^{47}$ Susabda Yakub B., Seri Pengantar Teologi Modern 1, 144.
} 


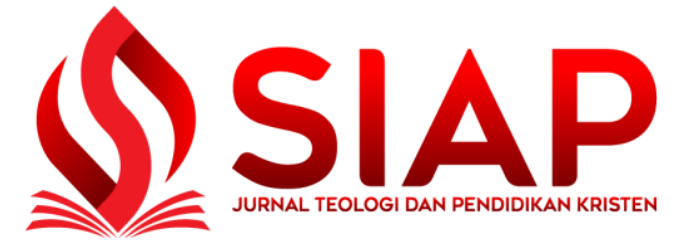

dalam dunia ini. Inilah makna keselamatan yang sesungguhnya. Dan keselamatan ini telah dialami oleh orang-orang di luar gereja, daripada mereka yang dialami oleh orang Kristen. ${ }^{48}$ Teologi Roma Katolik Pada Masa Kini

Pada masa sekarang gereja Katolik lebih terbuka dalam memahami keselamatan. Pada masa lalu, gereja Katolik menekankan bahwa gereja adalah satu-satunya saluran anugrah Allah. Anugrah itu tersalurkan melalui sakramen-sakramen yang dilaksanakan gereja. Anugrah ini bersifaf eksklusif sehingga orang-orang diluar gereja Katolik tidak dapat menerimanya. Hanya gereja yang memiliki ijin ekslusif untuk membagi-bagi anugrah ilahi. ${ }^{49}$ Pandangan ini telah mengalami perubahan karena gereja Roma Katolik masa kini lebih terbuka kepada pemahaman protestan mengenai pembenaran bahwa dalam aspek keselamatan manusia bersikap pasif sedangkan Allah aktif. Demikian juga gereja Katolik lebih toleran terhadap pendangan Luther tentang anugrah.

\section{KESIMPULAN}

Isu Sotereologi dalam Perjanjian Lama lebih menekankan pada keselamatan lahirian bukant batiniah. Sedangkan dalam Perjanjian Baru, keselamatan anugrah Allah yang diterima dengan iman iman kepada Tuhan Yesus Kristus dan keselamatan menjadi sempurna oleh karena perbuatan. Dalam sejarah perkembangan teologi Kristen terdapat 3 pandangan tentang keselamatan, yakni: pertama, Pandangan yang menekankan bahwa keselamatan adalah Anugrah Allah. Pencetus pandangan ini adalah Agustinus yang kemudian diteruskan pada masa Reformasi oleh Marthin Luther dan John Calvin. Kedua, Pandangan yang menekankan pada Anugrah Allah dengan keterlibatan manusia, yakni pandangan dari bapa-bapak Apostolik seperti Clement, Polikarpus, Pelagius, Semi Pelagius dan Armenius. Ketiga, Pandangan yang menekankan pada usaha sendiri sebagaimana yang diajarkan oleh teolog-teolog pandangan-

\footnotetext{
${ }^{48}$ Erickson Millard J, Teologi Kristen Volume 3, 90.

49 Ibid., 91.
} 


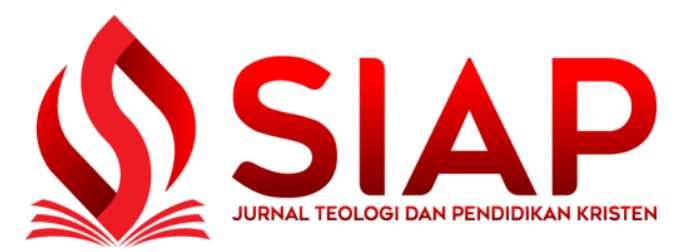

Vol. 10, No. 2 (Desember 2021)

Available Online at :

https://ejournal.sttjki.ac.id/index.php/siap/index

ISSN : 2302-5336X (Cetak) 2808-0459 (Online)

pandangan dari teolog modern. Bahkan pandangan mereka juga seringkali bertentangan dengan Alkitab. 


\section{BIBLIOGRAFI}

Berkhof H.; Enklaar I.H. Sejarah Gereja. 12th ed. Jakarta: BPK Gunung Mulia, 1994.

Browning W.R.F. Kamus Alkitab. Jakarta: BPK Gunung Mulia, 2008.

Douglas J.D. Ensiklopedi Alkitab Masa Kini Jilid II. 2nd ed. Jakarta: Yayasan Komunikasi Bina Kasih, 1996.

E., McGrath Alister. Christian Theology An Introduction. 2nd ed. Australia: Blackwell Publishing, 2008.

Enns Paul. The Moody Handbook Of Theology. 2nd ed. Malang: Literatur SAAT, 2010.

Erickson Millard J. Teologi Kristen Volume 3. 2nd ed. Malang: Gandum Mas, 2018.

Hadiwijono Harun. Teologi Reformasi Abad Ke 20. 6th ed. Jakarta: BPK Gunung Mulia, 2004.

Hoffecker, W Andrew; Smith, Gary Scott. Membangun Wawasan Dunia Kristen Volume 2: Alam

Semesta, Masyarakat Dan Etika. Edited by Hoffecker W. Andrew. 1st ed. Surabaya:

Momentum, 2018.

Lane, Tony. Runtut Pijar Sejarah Pemikiran Kristen. 6th ed. Jakarta: BPK Gunung Mulia, 2005.

Lutzer Erwin W. Teologi Kontemporer. 3rd ed. Malang: Gandum Mas, 2005.

Matalu Muriwali Yanto. Dogmatika Kristen Dari Perspektif Reformed. 3rd ed. Malang: GKKR (Gereja Kebangunan Kristen Reformed), 2017.

Susabda Yakub B. Seri Pengantar Teologi Modern 1. 2nd ed. Jakarta: Lembaga Reformed Injili Lindonesia, 1993. 